\title{
Identifying Pedagogical Implications for Teaching Application Letter: Learning from an Expert Text
}

\author{
Yeni Latipah, Wawan Gunawan \\ English Education Study Program \\ Universitas Pendidikan Indonesia \\ Bandung, Indonesia \\ yenilatipah@upi.edu
}

\begin{abstract}
Job application letter is a type of short functional text learnt by secondary school students. The ability to write a convincing and persuading job application letter is important for students to attain their intended job after graduating. Yet, the genre of an application letter is still less studied and there is little guidance on how to write the text to meet its communicative purposes. Thus, this study conducted a comparative analysis of an expert and student job application letter as well as the proposed pedagogical implication of how to teach to write an application letter. The analysis process employed Systemic Functional Linguistics (SFL) theory which includes the analysis of genre, register, discourse, and graphic features. The findings reveal that students have followed a sample genre of writing, but showed the need for improvement in the aspects of metafunction, conjunction, grammatical structures, spelling and punctuation accuracy. However, the most significant gap which was found between the expert and students' texts is the students' lack of ability to self-appraise. The study suggests that explicit instruction could raise the students' awareness of using a persuasive register.
\end{abstract}

Keywords: application letter, expert text, textual comparative analysis, Systemic Functional Linguistics

\section{INTRODUCTION}

The ability to write job application letters is important to be learnt by students since it performs a crucial function in acquiring a job. An application letter is a type of business letter that is written by a job applicant for prospective employers that the main purpose is to express interest in a particular position and to show the relevant abilities and qualifications possessed by the applicant (Paramasivam \& Rahim, 2016). Currently, in the context of Indonesian education, the job application letter, which also called a cover letter, is one of the texts learnt by the twelfth grade of senior high school students (Kusumayanti, 2018). However, among the other genres and text types which exist in the curriculum, the genre of an application letter is still less studied (Paramasivam \& Rahim, 2016). Additionally, there is little guidance on how to write the text to meet its communicative purposes. Thus, it is considered necessary to conduct more studies or analysis on application letter created by students in order to attain a real portrait of their abilities in writing the text.

Toward that case, conducting text analysis generally use systemic functional linguistics (SFL) as a framework of text analysis. SFL theory believes that every text-primarily comprises two levels; the context of a culture which is also called genre and the context of a situation encoded in a register (Lai, 2010). Genre is concerned with how people use language to achieve culturally appropriate goals. According to Knapp and Watkins (2005), genre relates to the social context in which a text is made. Genre is identified through the stages and goals of a text (Martin \& Rose, 2008). Regarding the genre of application letter, most of the employers spend approximately 10-20 seconds reviewing a letter. The job application letter, therefore, is a text type that requires features that allow for expediency in reading (Paramasivam \& Rahim, 2016). It has to be correct (accurate surface features such as spelling, sentence grammar, lexical accuracy), clear (informativeness in terms of meaning components) and wellstructured and captivating (stages and phases) (Bhatia, 1993). Furthermore, Butt, Fahey, Feez, Spinks, and Yallop (2001) stated that there are three parameters of the context of the situation. Those affect the language choices because they reflect the three main functions of language which Halliday (2004) named these three main functions as the ideational (experiential and logical), interpersonal, and textual metafunctions.

From the three metafunctions stated above, one of the important dimensions of interpersonal function is the appraisal. Appraisal is operated as one of the three major discourse semantic resources constructing interpersonal meaning (alongside involvement and negotiation) (Martin \& White, 2005). Concerning the present study, selfrepresentation in job application letters needs to be persuasive that it should contain an appropriate emotional response to the readers and achieve credibility. Self-appraisal is used as the main strategy to persuade the prospective employer to accept the candidature of the applicant and permit him or her an interview (Bhatia, 1993).

Apart from those, previous literature which focuses on the analysis and writing instructions of job application letter in the area of ESL/EFL have been conducted by several researchers. Paramasivam \& Rahim (2016) conducted the discourse and genre analysis study of students' job application letters. They found that the students' self-appraisal is rather weak because it is limitedly found in the letter. Moreover, Swami (2008) evaluates the efficacy of explicit genre-based instruction by sensitizing the ESL learners to the concept of the genre using job application letters as the authentic material. The result revealed that explicit instruction on genre promoted the students' improvement not only on their confidence to handle genres but also their attitude toward language learning. The research is quite similar to Portman (2014) who examined the learners' development in writing job application letters by introducing them a Systemic Functional Linguistics (SFL) 
approach to genre. He found that the approach promotes the learners improvement in appropriate expansion, organization, and variation of repertoire as well as resemiotisation and demonstration of practical and discursive knowledge in writing job application letter.

From those previous studies, it seems that there is still an area waiting for further research related to students' problems in writing application letters and practical teaching implications based on the problems. Hence, this study is intended to fulfill the gap by conducting a comparative analysis of job application letter written by an expert and students. The analysis aims to find the differences between the two texts that may consider the students' problems in writing a job application letter. After acknowledging the problems, a pedagogical implication or recommendation of activities was designed to diminish the problems. Through examining the common errors and linguistics difficulties that often created by EFL students and the proposed way to overcome it, the result of this study is expected to be a fruitful reference in improving the teaching of job application letter, in terms of syllabus designs and instructional activities, specifically towards the context of EFL education such as in Indonesia.

\section{METHOD}

\section{A. Research Design}

This study is a descriptive study that employs Systemic Functional Linguistics (SFL) theory as a method of text analysis. It is because SFL provides a useful framework for the purpose of analyzing a text (Banks, 2002). Moreover, the technique of text analysis utilized in this paper is referred to the book Reading to Learn: Assessing Writing (Rose, 2016). The book adopts Halliday's theory of SFL-based pedagogy and offers the basic techniques for analyzing the genre, register, the three simultaneous meta-function, cohesive patterns in text (reference, lexical cohesion, and conjunction) and graphic features (spelling, punctuation and presentation).

\section{B. Site and Participants}

As previously mentioned, there are two types of job application letter which are analyzed in this study; expert text and student text. The expert text was written by the researcher's friend who is currently studying in Monash University majoring in Applied Linguistics. He has performed a good quality in writing as well as an academic achievement by finishing his first semester with a GPA of 4.0. This expert text is used by the writer to apply for a job in Australia. Considering his academic background and his ability in English writing, the researcher decided to put his cover letter as the expert text. Meanwhile, the students' texts were written by four vocational high school students in the context where English is a foreign language. To rich the variety of analysis, the students' texts were selected randomly based on the students' major and academic level.

\section{Data Collection Process}

Both of the experts and students' text were collected by several processes. First, the expert text was gained through personal contact with the author who granted his permission to allow his cover letter to be analyzed and further sent the text through the researcher's e-mail. Secondly, the students' texts were collected by a Vocational High School teacher who is also the researcher's companion. Some instructional steps were applied before collected the texts. First, the teacher gave students materials of how to write job application letter by explaining and showing some examples of cover letter. After that, she asked the students to write their own application letter in their own version (independent construction stage). They were asked to write a letter based on job advertisements that they have found in any kinds of media. Additionally, in writing the letter, the teacher asked the students to suppose themselves as a vocational high school graduates and intent to write job application letter for starting their job experience.

\section{Data Collection Analysis}

Before comparing the expert and students' text, both texts were analyzed based on the book Reading to Learn (Assessing Writing). Firstly, the analyses start with identifying the stages and phases of the text. This is intended to show how this text could address the right order of generic structure of application letter and to clarify the realization of genre in each paragraph. The second analysis process conducted in this paper are in the level of register (field, tenor and Mode) based on the three strand of metafunction; interpersonal (mood and residue analysis), ideational (transitivity analysis) and textual (Theme and Rheme analysis). The third analysis is cohesive analysis including lexical cohesion, conjunction and reference. Furthermore, each clause of the text are also analyzed according to its grammatical structure and graphic features including the accuracy of spelling and punctuation.

\section{FINDINGS AND DISCUSSION}

The analysis of the expert and student texts reveals some important findings. All of the findings are presented in the following paragraphs.

\section{A. Genre (Purposes, stages, \& phases)}

In terms of purposes, both of the experts and the students' texts have been arranged in a well-organized generic structure including the date, addressee, subject of the letter, salutation, opening, content, closing, and signature. From that point, both of the texts have followed the right stages of the job application letter by which the purpose of the cover letter which is to provide the applicant information and interest toward a certain position, has been fulfilled. However, in relation to the phases, the expert text gives more clear logical sequence in bridging each paragraph with providing a statement such as "through this cover letter" or "in relevance toward the working experience" compare to the students texts which are mostly still in problems with elaborating information and connecting statements.

\section{B. Register (Field, Tenor \& Mode)}

As stated in the previous chapter, register is realized by three dimensions; field, tenor and Mode. First, the establishment of field in the analyzed text which manifested by the ideational meta-function reveal that material process is the most dominated process found on both of the texts followed by relational and mental process. It could be referred that the 
expert and the students have tried to give their factual information or thought in the text. As referred to Portman (2014) who argued that material processes helped show what the candidate had done as part of prior experience, in an attempt to demonstrate that the candidate was suitable for the job.

Secondly, in relation to the establishment of tenor in the text which realized by interpersonal meta-function, covers the notions of modality, tenses, mood, polarity, and appraisal. Yet, the appraisal system will be elaborated separately in the following paragraph. The results of the expert and students' text reveal that the student texts have lower modality appearance than the expert text. In terms of tenses, both of the texts perform a variety of tenses including present, past, present continues, present perfect and future conditional tenses. However, the student texts show some errors in the use of tenses such as "I finish my pre-service training on January this year" in which it should be in the past form. Furthermore, all the sentences in both expert and student texts are descriptive sentences, with low negative polarity. It is in line with one of the purposes of the cover letter which is to describe or elaborate information about the applicant which suitable with the job criteria.

Related to the Mood analysis, the word "I" performed as the most appearing subject in both of the texts which indicate their attempts to be the center attention by positioning 'I' as the subject. In the expert text, the thematic progression implies zigzag pattern to achieve the cohesion by building on newly introduced information as well as theme reiteration where the same elements occur regularly as themes and provide the paragraph with a clear focus to help maintain a strong topical focus. Meanwhile, in the student texts, the most common theme is the theme re-iteration because it only focuses on the subject 'I'.

Moreover, In terms of Mode, some spoken words could be found in the student texts which perhaps inappropriate especially to be delivered in an application letter. For instances, the student stated "I am 20th years old, famale, single" without any conjunctions or connector. It means that some students may have difficulties to shift the spoken words into written ones.

\section{Lexis}

Similar to the expert text, most of the student texts contain selected words/phrases that commonly exist in application letter such as job opportunities, company, position, interview and etc. Those words/phrases are also repeated several times such as company and leads. Thus, the student probably has been known the discourse of application letter even though it may be still insufficient to convince the reader because those words/phrases are not supported by further elaboration of personal judgment or value.

\section{Appraisal}

The researcher considers that the biggest gap which may be detected between the expert and the student text is the lack of appraisal provided by almost all of the student text. There are only one or two appraisal which could be found on the student text such as "I can work hard, diligent and honest" or "I have good motivation for progress and growing, eager to learn, and can work with a team or by myself". In contrast, the expert has established more value with give self-appraisals which suitable to his intended position to achieve the intention of the presumed reader. For example "I am interested in building and implementing my customer service skills internationally by working as a Customer Service Officer in your department" or "I believe that I could effectively take the role as a Customer Service Officer and confirm my genuine interest in both the position and your organization". Toward the case, the offerings of appraisals used by students are lacked clarification of the relevance for the position applied for. In other words, although they try to present their self-promotion, the students did not indicate how these were linked and could be useful and valuable to the company (Paramasivam \& Rahim, 2016).

\section{E. Conjunction \& Reference}

Regarding the use of conjunctions, most of the students did not employ many conjunctions to build the logical relation and coherencies of the text. There are only "and" or "or" which could be found on the student texts. On the other hand, related to the use of reference, they seem to be able to use appropriate references in writing a text. In comparison, the expert texts used several conjunctions to show the complex sentences and to connect sentence to sentence such as "however", "besides", and "lastly". Many repetitions have also appeared in the expert text to stronger the explanation, synonym and personal references such as "I" to emotive the personal persuasive promotion.

\section{F. Grammatical accuracy}

In relation to grammatical accuracy, there is no grammatical error found in the expert text. On the other hand, some students which considered in the middle and low level of English proficiency produced many grammatical errors in their texts. Those are generally about subject-verb agreement, tenses, part of speech and many else. For examples, "I confident" which should be "I am confident" or "my background educational" which should be "my educational background". Thus, it could be assumed that the students in middle and low level of English proficiency may have a trouble in composing a fully correct application letter because of the grammatical errors.

\section{G. Graphic Features (Spelling, Punctuation \& Presentation)}

In terms of spelling and punctuation, it is found that students produced spelling errors on their texts such as "Sincrerely", "famale", "Bansung" or "carrer" . It seems that the students which from the middle and low level were not paying attention carefully to their writing. They also produce punctuation errors which further make their application letter become less accurate.

Furthermore, the expert presents his cover letter in the form of effective narration. Meanwhile, the student texts were performed by paragraphs and list of points. The paragraphs only contain the information without any attempt to further elaborate the information to convince the readers. Besides, most of the students only give short description about themself and it seems inadequate to persuade the job receiver. They also does not strengthen her educational background and achievement or their experiences at least by mentioning her pre-service training experiences. 


\section{H. Pedagogical Implication}

Throughout all the analysis, it appears that the student texts have already followed the genre of job application letter, specifically in its purpose, stages and text structures. In terms of cohesive analysis, the student texts also represent a variety of word and phrase choices which helped them in conveying the message they intend to tell. Yet, some students still produce grammatical, spelling and punctuation errors on their texts which reduce the quality of their application letter.

However, the findings show that the main problem encounter by the students in producing a job application letter is their ability to create self-appraisal. The students were not able to establish their relevance to the job and to self-appraise. They did not translate or transform their knowledge, experience and skills into capabilities that would be useful to the company by which an employer would look for in a potential employee. It rejects the concept of writing job application letter such as proposed by Bhatia (1993) who notes that the primary function of a job application letter is to promote the candidature of the writer by allowing the candidate to demonstrate possession of relevant qualities for a particular job.

Concerning the problem, explicit instruction that emphasized the concept of appraisal system seems to be worth implemented in the lesson plan. Introducing students with appraisal theory is expected to build their awareness of the persuasive language commonly appeared in the text. Thus, the awareness of self-appraised could influence their language choice in writing more convincing and persuading statements in application letter. It is in line with the argument from Bhatia (1993) who claimed that the ability to self-appraise or selfpromote is key to the persuasive appeal of the job application letter and it supports the statement of Rose (2006) who argued that students learn English through explicit teaching of language and immersion in a diverse range of purposeful and increasingly demanding language experiences. It is also suitable with the previous studies who confirm the significant impact of explicit instruction of appraisal toward the students' ability in writing (Zhang, 2018; Swami, 2018)

The below activities are designed as the realization of what it is called explicit instruction of appraisal in teaching job application letter. The activities are mostly adopted from Rose (2006) and targeted towards the twelfth grade students of vocational high school because the topic of application letter is available in their syllabus. As presented in Table I.

\section{TABLE I. EXPLICIT INSTRUCTION OF APPRAISAL IN TEACHING} APPLICATION LETTER

\begin{tabular}{|c|c|}
\hline Stages & Activities \\
\hline $\begin{array}{l}\text { Building } \\
\text { Knowledge }\end{array}$ & $\begin{array}{l}\text { - Introducing paragraphs contains of appraisal. } \\
\text { - Students are prepared to recognize and understand } \\
\text { appraisal within each sentence using cues, so that } \\
\text { students know what it means, and where to find it } \\
\text { in the sentence. } \\
\text { - Listening to job interview while providing the } \\
\text { students with the script of the interview. } \\
\text { - Asking students to analyze the type of appraisal in } \\
\text { self-promote by underlining the script. }\end{array}$ \\
\hline Modelling & $\begin{array}{l}\text { - Exposing learners to the samples of good quality } \\
\text { of application letter. }\end{array}$ \\
\hline
\end{tabular}

\begin{tabular}{|c|c|}
\hline & $\begin{array}{l}\text { - Underlining/ highlighting/ labeling the appraisal } \\
\text { found on the expert text } \\
\text { - Comparing the expert and their own text by note } \\
\text { making which focus more on self appraisal. } \\
\text { - Teacher then elaborates by defining, explaining or } \\
\text { discussing the appraisal in more depth. }\end{array}$ \\
\hline Joint Construction & $\begin{array}{l}\text { - Students are asked to response to job } \\
\text { advertisements. They are asked to create } \\
\text { sentences/statements containing their self- } \\
\text { promotion/glorification to show their suitability } \\
\text { to the jobs. } \\
\text { - The teacher guides the students to write their own } \\
\text { application letter using the sentences and the } \\
\text { notes (from modeling step). }\end{array}$ \\
\hline $\begin{array}{l}\text { Independent } \\
\text { Construction }\end{array}$ & $\begin{array}{l}\text { - Following completion of job application letter, } \\
\text { students' writing was first read by their } \\
\text { classmates, who provided written feedback. } \\
\text { - The instructor verified or negated peer feedback } \\
\text { and provided further feedback through a written } \\
\text { channel. } \\
\text { - The students wrote their final application letter. }\end{array}$ \\
\hline
\end{tabular}

The strategies for teaching job application letter presented above will mostly focus to building knowledge and modeling steps. The two steps could support students to acknowledge self-appraisal, finding key information of appraisal in an effective job application letter, and using this information in their own writing. Those activities could facilitate students to critically interpret texts they are reading and writing, and to prepare them for independent construction.

Toward the senses, the pedagogical implications drawn from the findings of the study could work as a pedagogical tool which creates some benefits.

First, explicit instruction on appraisal could develop a student's communicative purpose. Explicit instruction of the appraisal system (Martin \& White, 2005) would help the teachers able to show learners how to demonstrate solidarity with their presumed readers by showing common values with them. By listening comprehension to the job interview in building a knowledge step, students would acknowledge how to persuasively glorify their strong points. For example, instead of stating "I'm hardworking person", students might highlight their hardworking nature through examples of school-related activities, trainings, or organizational experience (Portman, 2014). Thus, such an ability would help them achieve the communicative purpose of job application letter which is to provide persuasive appeals by showing the possession of relevant qualities (Bhatia, 1993).

Second, explicit instruction could facilitate students to fill the reader's expectations. In the second step of the instruction (modeling), the learners are exposed to the sample of good quality of job application letter. By this activity, learners being made aware that job application letters are embedded by certain self-advertised statements because the writers of application letters must imaginatively construct a persona that matches the expectation of potential employers toward the successful applicant. This awareness would further help them determine the choices and constraints of text production. It is related to Hyland (2003) who assumes that every successful text will display the writer's awareness of its context and the readers who form part of the context. Therefore, activating students with 
how to self-appraise could smoothly lead them to show their relevant qualities in their application letter that yield the potential employer expectations.

Additionally, students could transfer their knowledge of appraisal to other text types. For example, in the building knowledge step, students are introduced towards appraisal and asked to find the appraisal in the paragraphs. Hence, it could be assumed that providing the learners with the explicit teaching of the appraisal system could open the possibility to transfer the knowledge of appraisal from job application letter to another text type. It is proved by the previous studies that explicit instruction of appraisal could facilitate students gradually gained an enhanced understanding of interpersonal meaning as readers and authors in another text type such as expository and argumentative writing (Zhang, 2018).

\section{CONCLUSION}

The findings of the expert and student text analysis reveal that in terms of genre and cohesive device, both of the texts have followed the appropriate stages and text structures as well as presented a variety of word and phrase choices commonly available in a job application letter. Furthermore, even though some students still produce grammatical, spelling and punctuation errors in their texts, the aspect considered as the most significant gap between the expert and the student text is the students' ability to create self-appraisal. As a response toward the problem, explicit instruction that emphasized the concept of the appraisal system is the recommendation proposed in this study. Introducing students with appraisal theory is expected to build their awareness of the persuasive language commonly appeared in the text. Thus, the awareness of self-appraised could influence their language choice in writing more convincing and persuading statements in the application letter.

\section{REFERENCES}

Banks, D. (2002). Systemic functional linguistics as a model for text analysis. La Revue du GERAS, 35-36. doi: 10.4000/asp.1584.

Bhatia, V. K. (1993). Analyzing genre: Language use in professional settings. London: Longman.

Butt, D., Fahey, R., Feez, S., Spinks, S., \& Yallop, C. (2001). Using functional grammar: An explorer's guide ( $2^{\text {nd }}$ edn.). Sydney: National Centre for English Language Teaching and Research.

Halliday, M. A. K. (2004). An introduction to functional grammar. New York: Oxford University Press.

Hyland, K. (2002). Genre: Language, context, and literacy. Annual Review of Applied Linguistics, 22, 113-135. doi: 10.1017/S0267190502000065

Knapp, P., \& Watkins, M. (2005). Genre, text, grammar: Technology for teaching and assessing writing. Sidney: UNSW Press.

Kusumayanti, D. (2018). Rencana pelaksanaan pembelajaran (RPP) SMK NU Gresik. Retrieved from http://eprints.umg.ac.id

Lai, J. (2010). Interpersonal functions of EFL teachers' evaluative discourse. International Education Studies, 3(2), 167-173. doi: 10.5539/ies.v3n2p167

Martin, J. R., \& Rose, D. (2008). Genre relations: Mapping culture. London: Equinox.

Martin, J. R., \& White, P. R. R. (2005). The language of evaluation: Appraisal in English. New York: Palgrave.

Paramasivam, S., \& Rahim, M. I. (2016). Genre analysis of job application letters in Malaysia. The Asian ESP Journal, 12(2), 144-171.

Portman, D. (2014). Walking a linguistic tightrope: Learner development in writing job application letters (Unpublished master's thesis). The Open University.

Rose, D. (2006). Scaffolding the English curriculum for indigenous secondary students: NSW 7-10 English syllabus Aboriginal support pilot project office of the board of studies. Final report. Retrieved from https://abed.nesa.nsw.edu.au/files/Scaffolding_Literacy_Evaluation_Rose.pdf

Rose, D. (2016). Reading to learn: Assessing writing. Retrieved from http://www.readingtolearn.com

Swami, J. A. (2008). Sensitizing ESL learners to genre. Teaching English as A Second or Foreign Language (TESL-EJ), 12(3), 1-13.

Zhang, X. (2018). Supporting EFL learners' reflective practices through systemic functional linguistic praxis: A longitudinal case study Educational Sciences: Theory \& Practice, 18, 495-513. doi: 10.12738/estp.2018.2.0022 